\title{
Sustainable Development Goals (SDGs) Principle Towards Sharia Business Unit Pre-Spin Off 2023
}

\author{
Nikmah Mentari and Franciska Mifanyira Sutikno \\ Postgraduate Program, Faculty of Law, Universitas Airlangga, Surabaya, Indonesia \\ E-mail: franciska.mifanyira.sutikno-2017@ fh.unair.ac.id
}
How to cite : Nikmah Mentari and Franciska Mifanyira Sutikno. "Sustainable Development Goals (SDGs) Principle Towards Sharia Business Unit Pre-Spin Off 2023". UNIFIKASI : Jurnal Ilmu Hukum. 6(2) 2019. 199-208. DOI : 10.25134/unifikasi.v6i2.1866
Submitted : 14-07-2019 Revised : 06-11-2019
Accepted : 15-11-2019

\begin{abstract}
The existence of a Sharia Business Unit will be ended in 2023 due to the mandate of the Sharia Banking Act which requires a spin-off. Therefore, the Sharia Business Unit will become an independent Sharia Bank. As part of the parent bank, it is should for the conventional bank to prepare the readiness of Sharia Business Unit before spin-off so that it can compete in the global era based on the SDGs principle and still maintain the sharia compliance. The method applied is normative juridical, which relates to the prevailing norms and legal principles. The outputs are produced by focusing the objectives on SDGs goals which are correlated with Sharia Banking and Good Corporate Governance principles of Sharia Business Unit with Conventional Bank.
\end{abstract}

Keywords: Coventional Bank, SDGs, Sharia Business Unit, Spin Off

\section{Prinsip Tujuan Pembangunan Berkelanjutan Menuju Pre-Spin Off Unit Bisnis Syariah 2023}

\begin{abstract}
Abstrak : Keberadaan Unit Usaha Syariah akan berakhir pada tahun 2023 berdasarkan amanah UndangUndang Perbankan Syariah yang mensyaratkan adanya spin-off. Oleh karena itu, Unit Usaha Syariah akan menjadi Bank Umum Syariah yang mandiri. Sebagai bagian dari induk bank, Bank Konvensional seharusnya menyiapkan Unit Usaha Syariah sebelum terjadinya spin-off sehingga Unit Usaha Syariah dapat bersaing di era global berdasarkan prinsip SDGs dan tetap mempertahankan kepatuhan syariah. Metode penelitian ini yakni normatif-yuridis yang berhubungan dengan norma dan prinsip hukum. Hasil yang diperoleh berfokus pada sasaran tujuan SDGs yang berhubungan dengan Perbankan Syariah dan prinsip Tata Kelola Perusahaan yang Baik pada Unit Usaha Syariah dengan Bank Konvensianal.
\end{abstract}

Kata Kunci : Bank Konvensional, SDGs, Unit Usaha Syariah, Spin-off

\section{INTRODUCTION}

Global Era and International relations urge the society to unite and prepare the bigger named sustainable development. Sustainable Development as created by United Nations is not only concernng and encouraging one state to enhance the relationship to other state but it helps the states to aware and plan the better life for the state though complex developments. This agenda has implemented to a real issue named Sustainable Development Goals (hereinafter called SDGs) by its catching quotes named "No One Shall not be left behind". SDGS also related to the Banking Principle to gibe mutual prosperity besides to maintain the effective and ensurement of people interest and fund allocation to the society. ${ }^{1}$ SGDS is a result continuation of Millenium Development Goals (MDGS) ended in 2015, that continuation from MDGS to SDGS is a concrete plan to end the society issue along with the intention to encourage the business sectors players to join in order for harmonizing the development. ${ }^{2}$ Business activities by society should be enhanced by ideal institution intended as an intermediary between parties who have excess funds and those who lack funds as

\footnotetext{
${ }^{1}$ Lukmanul Hakim, "Credit Banking in Business Law Perspective”, Jurnal Ilmu Hukum Unifikasi, Volume 6, Nomor 1, Tahun 2019, p. 53.

${ }^{2}$ Ishartono and Santoso Tri R, "Sustainable Development Goals (SDGS) dan Pengentasan Kemiskinan”, Share : Social Work Jurnal, Volume 6, Nomor 2, Tahun 2016, p.159.
} 
reflected in Bank ${ }^{3}$. The banking system in Indonesia namely is dual banking system. ${ }^{4}$ Dual Banking system is implemented since there is a huge diversities of Indonesia Religion doers, giving a fact that Moslem Religion is a majority. Since Moslem Religion is complex and different from the other religion, government and society agreed to implement sharia product into business and financial sectors. Since then Indonesia acknowledge the Sharia Bank and Conventional Bank as the pillar. Both Sharia and Conventional bank is required to concern on every aspect of society and related to development, especially using precautionary principle. ${ }^{5}$ If Sharia Commercial Banks that established independently as legal subjects in the form of Limited Liability Companies, Conventional Banks is able to open 'Islamic Window' which allows the conventional banks to have their own Sharia Business Units based on sharia principles. Sharia Banks may have a relationship experience with customers in a different model compared to conventional banking. ${ }^{6}$ The relationship of Muslim customers to Sharia Banks may not be solely for economic reasons but also for ideological reasons. ${ }^{7}$ Sharia Banks bring maslahat 'for economic improvement and equal distribution of people's welfare as reflected in financing, non-speculative product, profit loss sharing system.

Indonesia government has taken serious intention and legal actions to implement the SDGs principle in the aspects of Government conducts and Government law products using Sharia Bank and provide an opportunity to redefine their role for training to people empowerment,socio-economic development and environment. SDG's agenda for enhancing these possibilities for Islamic Finance as the SDG goals and values has parallels of relevance and application with Islamic Finance practices. ${ }^{8}$ Islamic finance principles are highly aligned with the SDGs, and forging new partnerships in this area will be essential to provide the much-needed reinforcements to finance and implement 2030 Agenda. ${ }^{9}$ Based on the background of introduction, the legal issues that would be analyzed are : The Urgency of Conventional Commercial Banks Applying The Principles of SDGS to Pre-Spin Sharia Business Units Off 2023? ; SDGS Implementation after Sharia Business Unit Spin-Off.

\section{RESEARCH METHODS}

Research method used in this Research is Normative Positivist and also enhanced by several approaches such as Conseptual and Statute Approach. Normative Positivist Methods means that research would be focused in depth regarding the existence of Law and Regulations to analyze the legal issues. The Law and Regulations would be differ not only in the certain law but also law which contains of common rules to harmonize the explanation in research.

Statute Approach used to analyze the SDGS principle in Indonesia law and regulations. Statute Approach would be included all related law and regulations of Sharia, Banking, Finance and also SDGS as the main point. Conseptual used to complete and harmonize through consept in banking and/or other regulations related to SDGS and sharia. Conseptual Approach used to analyze the specific or common requirements or common activity and/or legal conduct of Sharia Bank in maintaining and implementing the SGDS Principle from law concept. The purpose of research are to

\footnotetext{
${ }^{3}$ Trisadini P. Usanti dan Abdul Somad, Hukum Perbankan, Kencana Prenada, Jakarta, 2018. p.1.

${ }^{4}$ Ibid.

${ }^{5}$ Muhammad Fardan N, "Mengawail Sustainable Development Goals (SDGS) Meluruskan Orientasi Pembangunan yang berkeadilan, Sosioreligius, Volume 1, Nomor 1, June 2015, p.81.

${ }^{6}$ Agus Triyanta. Implementasi Kepatuhan Syariah dalam Perbankan Islam (Syariah) (Studi Perbandingan anatar Malaysia dan Indonesia. Jurnal Hukum Ius Quia Iustum Volume 16, Oktober 2009, p. 211. https://media.neliti.com/media/publications/81025-ID-implementasi-kepatuhan-syariah-dalam-per.pdf ${ }^{7}$ Ibid.

${ }^{8}$ Abdul Ghafar Ismail. Et.all (2018, July 11-12). Ecosystem in Islamic Finance and Its Link with SDGs. 3th International Conference on Islamic Economics and Finacial Inclusion, Universitas Muhammadiyah Yogyakarta, p. 4, http://iciefi.umy.ac.id/wp-content/uploads/2018/07/Prof.-Abdul-Ghaffar-ecosystem_IF.pdf

${ }^{9}$ Islamic Development Bank and United Nations Development Program. Islamic finance partnerships key to implementing Sustainable Development Goals, 22 September 2016, https://www.isdb.org/news/idb-and-undp-islamic-financepartnerships-key-to-implementing-sustainable-development-goals. without page.
} 
analyze the urgency and implementation of SGDS in Indonesia after Sharia Business Unit Spin Off and also analyze the practical implementation to Sharia Bank in doing and preserving the means and/or planning of SDGS by government.

\section{RESULTS AND DISCUSSION}

\section{Urgency of Conventional Commercial Banks Applying The Principles of SDGS to Pre-Spin Sharia Business Units Off 2023}

The legal relationship between a conventional commercial bank and its Sharia Business Unit is not a holding company relationship between a parent company and a separate subsidiary based on the principle of a separate legal entity. This legal relationship is included in the management relationship where Sharia Business Unit is still in the management of a conventional bank, only having exclusivity related to the application of sharia principles. The position of Sharia Business Unit is only as part of its own department which has similarities with other departments in the ranks of organs of Conventional Bank directors. ${ }^{10}$ Eventhough the legal relationship mostly concern on business principle and administration of Commercial Bank rather than focusing the Business Unit, Comventional Bank has another point to establish Sharia Business Unit than Commercial Unit to gain the market position and giving the society an ease to choose using sharia banking based on religious matters. Morevover, the option of choosing the Sharia Banking unit has already modified as islamic law combined with business importance by giving the Commecial Bank to implement Islamic Windows and/or Office Channeling. ${ }^{11}$ Both options between Islamic Windows and Office Channeling still giving Commercial Banking rights to supervise and support the Sharia Business Unit by legal and appropriate way in financial and/or management depends on the needs.

It is reasonable if the Conventional Bank as the parent company of the bank has an important role in the process of releasing the Sharia Business Unit to become a Sharia Bank. Law Number 21 of 2008 concerning Sharia Banking Article 68 Paragraph (1) states, In the event that a Conventional Bank has a Sharia Business Unit whose asset value has reached at least 50\% (fifty percent) of the total asset value of its parent bank or 15 (fifteen) the year since the enactment of this Law, the said Conventional Bank must conduct the Separation of Sharia Business Unit into a Sharia Bank. The separation should let Sharia Business Unit to be independent and freshly established as new legal entity rather than controlled by Commercial Bank through management, shares and/or cooperation contract. The separation of Sharia Banking Unit to be renew as Commercial Banking would be assesed by authorities in administrations and also the implementation and readiness of new managers and/or directors. The assesment would also related to Due Dillegence and administration license. Amalia Nasuha ${ }^{12}$ mentions the obligation to conduct a spin-off describing an additive or derivative product or derivative or the result of an imitation of a previous business. The Spin Off of Sharia Bank has no difference and should be based on Company Law which divides spin off mechanism as "pemisahan murni" and "pemisahan tidak murni" depends on how much and legal consequences of those spin off. ${ }^{13}$ Spin off might be done by merger and/other way as long as spin off legal elements related to the readiness has accomplished.

\footnotetext{
${ }^{10}$ Bank Jatim. Profil Bank Jatim,,. https://bankjatim.co.id/id/tentang-bankjatim/manajemen/struktur-organisasi , without page.

${ }_{11}$ Sulasi Rongiyati, "Pengembangan Perbankan Syariah Melalui Pelaksanaan Perbankan Syariah Melalui Pelaksanaan Kewajiban Pemisahan Unit Usaha Syariah", Negara Hukum, Volume 6, Nomor 1, Juni 2015, p. 66.

${ }^{12}$ Amalia Nasuha. Dampak Kebijakan Spin-Off Terhadap Kinerja Bank Syariah. Al-Iqtishad Volume 4 Nomor 2, Tahun 2016, p. 243.

${ }^{13}$ Khotibul Umam, "Peningkatan Ketaatan Syariah Melalui Pemisahan (spin-off) Unit Usaha Syariah Bank Umum Konvensional", Mimbar Hukum,Volume 22, Nomor 3, Oktober 2010, P. 609
} 
Readiness based on de facto and de jure condition would be a responsibility to government and/or Sharia Bank Managers and director since there are still many objections that leads to the gap between consept and theory on sharia banking law and practical implementation such as ${ }^{14}$

a. Goals shpuld clarify the parties who would bear the executions, especially related to the responsibility and competency if the spin off makes the decreasing results to the sharia banking;

b. Goals and spin off recommendation should not only focused on the sharia banking as exclusive affected parties, but also government should make structural reforms of supporting elements and/or institutional;

c. Goals of spin off should ensure human rights elements, not only related to the institutional and business like rights ;

d. Spin off should not related to political interests;

Other elements are technology transfer and ownership rights from the parent to the new owner. This is because the SDGs carry 5 fundamental principles that balance economic, social, and environmental dimensions, namely People, Planet, Prosperity, Peace, and Partnership. These five basic principles are known as $5 \mathrm{P}$ and overshadow 17 Goals and 169 Targets that are inseparable, interconnected, and integrated each other to achieve better human life. On the other side, banks can explore how they can engage with sustainable development issues by channeling financial capital and creating innovative products, services, and strategies based on an analysis of sustainable development needs ${ }^{15}$ or simply focusing the activity to the 17 goals. ${ }^{16}$ Before the Issue of The Separation is called spin-off. Spin-off is recognized, Indonesia has acknowledge the spin off principle in the Act Number 40 the year 2007 on Company Law. Article 1 paragraph (12) Company Law acknowledges that the characteristic of spin-off conducts are Separation of a Business entity, Active Income to Passive Income and/or asset being transferred to the receiver and The separated parties become the new legal entity. The Reason why Sharia Business Unit are addressed to be spin off rather than merger, consolidation and/or acquisition is to renew and refresh the underperforming operation which happened to the Sharia Banking Unit before, to maintain and encourage the Business Unit for making new markets, to re-focus on the mission and vision of Sharia Banking Unit as a truly Sharia Banking rather than controlled by Conventional Banking.

There are two points in article 68 paragraph (1) of the Sharia Banking Act on mandatory law regarding the spin off, first a UUS (Sharia Business Unit) whose asset value is $50 \%$ of the total assets of BUK is required to do spin off before 2023. Since the 15 (fifteen) years of the enactment of the Sharia Banking Act Sharia Business Unit can work as a foreign exchange bank or non-revised bank. As a special work unit, Sharia Business Unit has the duty to 1) regulate and supervise all sharia branch office activities, 2) implement treasury functions in the management and placement of funds sourced from sharia branch offices, 3) prepare consolidated financial statements from all sharia branch offices , and 4) carry out the administrative tasks of sharia branch office financial statements. Meanwhile as being stated in Article 19 paragraph (2), Sharia Business Unit also has some similarities of service for being served to the customers as well as Sharia Bank, this fact implicated that Sharia Bank and Sharia Business Unit is same nature as Sharia Bank. The difference between them is only related to the independence since Sharia Business Unit is controlled and supervised by Conventional Bank.

\footnotetext{
14 Thomas Pogge and Mitu Sengupta, “The Sustainable Development Goals as Drafted : Nice Idea, Poor Execution", Washington International Law Journal Association, Volume 24, Nomor 3, 2015, P. 573-579

15 Olaf Weber,. Financial Sector and The SDGs: Interconnections and Future Directors. Centre for International Governance Innovation Papers, Edisi Nobember 2018, Violume 201, p. 12-13. https://www.cigionline.org/sites/default/files/documents/Paper\%20No.201web.pdf

${ }^{16}$ Ibid.
} 
All Sharia Business Unit legal actions constitute responsibility and are also risky at Conventional Bank. Because it is only a unit, which means that it can be likened to one body part of a legal entity, the responsibility cannot be separated from the legal entity itself, unless the legal entity concerned removes, releases dissolves or negates the body part. Based on this description, it has become a moral responsibility for Conventional Bank to equip Sharia Business Unit better before the spin off occurs. The responsibility and role of the Conventional Bank in its Sharia Business Unit before spint-off is not merely preparing managerial and financial terms. However, in order to Sharia Business Unit to become a Sharia Bank that is ready to face global challenges, the application of the SDGs principle is homework for Conventional Bank. Conventional Bank cannot ignore Sharia Business Unit to be able to apply the SDGs principle, even though the Conventional Bank itself is preoccupied with developing the SDGs principle in its conventional business. Islamic finance's strong potential to promote financial inclusion and shared prosperity, are completely in line with the SDGs of ending poverty, mitigating inequalities and ensuring a more inclusive society. Financing particular in sharia banking is not only a fundamental need. They are business and job opportunities, strategic partnership with the private sector, support investments and business infrastructure, solidarity and participatory finance, enterpreneurship capacity building, strategic partnerships to access promising markets. ${ }^{17}$ Therefore, the SDGs Agenda enhances these possibilities for Sharia Banking as the SDG goals and values have parallels relevance and application with Islamic Finance practices particular in sharia bank. So, that is why SDGs important for Sharia Business unit before preparing become sharia bank.

\section{Implementation of the Sustainable Development Goals (SDGs) After the Sharia Business Unit Off Spin to Become A Sharia Commercial Bank}

Sharia Banking can take steps to prepare for the implementation of the SDGs in a number of steps.

Figure.1 Implementation id SDGs after spin off as produced by self-analysis

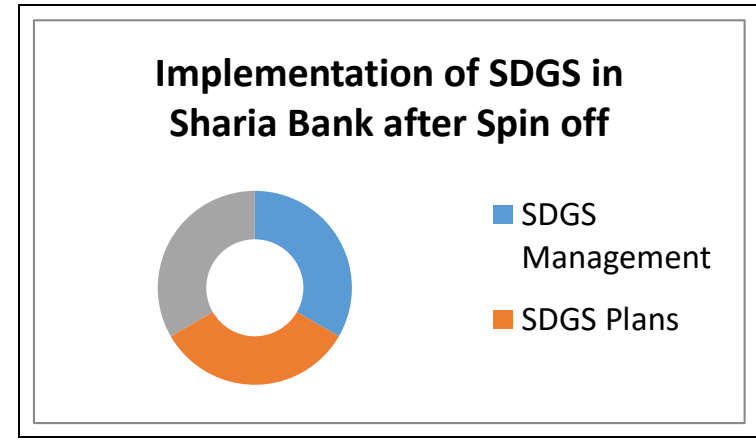

As Implemented in the Figure.1, SDGs implementation is Sharia Bank after Spin-off out from Sharia Business Unit are implemented into 3 (Three) but integrated factors: The Management, the Plans and The Alternate mechanism in Corporate Social Responsibility. These three factors are suitable to be implemented to the Sharia Bank for some reasons such as:

a. Sharia Bank is still a form of a Bank and also a Company.

b. In Operating a Bank, Sharia Bank managing parties should not only rely on the Managing rules but also has a vision of SDGS itself comprehensively.

c. Sharia Banking established and developed for the sake and from the role of society since it reflects Sharia Law.

\footnotetext{
${ }^{17}$ Rami Ahmad. The Potential of Islamic Finance in Achieving the SDGs : Sustainable Development Transition Forum 2017, Incheon, Republic of Korea, p. 21, https://www.asef.org/images/docs/2_Dr\%20Rami\%20AHMAD_IDB.pdf
} 
First, Management in the Implementation of the SDGs Program. Based on Sharia Bank Act and Sharia Banking System, Management is implemented in Article 38 Sharia Banking act into risk management which mainly only implemented to the financing services. On the other hand, management implemented also related to the Capability management into the financial aspect, sharia principle implementation, Islamic management and operational principle in Article 51 Sharia Banking act. Management as SDGs implementation is divided into General Management, Human Resource Management, and Capital Management :

a. Management (in general). Sharia Bank is required to continue implementing the Principles of Good Corporate Governance (GCG). Regulations concerning GCG are outlined in as outlined in Bank Indonesia Regulation Number 11/33/2009 concerning Implementation of Good Corporate Governance in Sharia Bank and Sharia Business Unit juncto Bank Indonesia Circular Letter Number 12/13 / DPbs April 30, 2010 concerning Implementation of Good Corporate Governance for Sharia Bank and Sharia Business Unit juncto Financial Services Authority Regulation Number 55 / PO] K.03 / 2016. The good corporate governance that is applied must be following the objectives of the SDGs to implement SDGs in Long Term Projections, namely Reform, Revolution and Reversal.

b. Human Resource Management. The Human Resources oriented in the SDGs should be according to Islamic Shari'a such as implementing the nature of employees who are Shidiq (Honest), Tabligh (bringing and disseminating goodness), Amanah (Trustworthy) and Fathonah (Smart) through both fit and proper tests and certifications In addition to these characteristics, the implementers of Sharia Banking must also understand the 3 (three) main pillars in Islam, namely Aqidah, Syariah and Akhlaq. In the implementation of Bank function in Human Resource Management and Development as Company, Sharia Bank should imply the conditions as stated in Law Number 13 Year 2003 on Labour Law. Based on Article 4 Labour Law. Asset and or Capital Management. Banking assets and capital are related to the soundness of the bank, so Sharia Bank is required to manage and supervise and carry out transparency on Capital,

c. Asset Quality, Earnings, Liquidity, Sensitivity to marker and management. ${ }^{18}$ Capital is also related to handling risks after the Sharia Business Unit becomes Spin-off. The risks that can be faced by Sharia Bank as Limited Liability Companies are related to financial factors, especially related to obligations, financial statements, Potential Inventories and Operational and Liabilities. ${ }^{19}$ One way to manage and create productive assets is through investment. Attributively the Investment mechanism is implemented in the Financial Services Authority Regulation Number 53 / POJK.04 / 2015 Concerning the Contracts used in Issuance of Sharia Securities in the Capital Market juncto Financial Services Authority Regulation Number 18 / POJK.04 / 2015 concerning Issuance and Requirements of Sukuk juncto Decree of Bapepam LK No. KEP-208 / BL / 2012 concerning criteria and List of Sharia Securities List (Regulation No. IX.A.13) juncto Fatwa of National Sharia Council Number 04 / DSN-MUI / I / IV / 2000 relating to Investment through Murabahah juncto Fatwa of Sharia Council National No: 05 / DSN-MUI / IV / 2000 relating to Salam Sharia Sale and other Securities Instruments as stipulated in the Capital Market Law. All of them must also be subject to the Financial Services Authority Regulation Number 15 / POJK.04 / 2015 concerning the Application of Sharia Principles in the Capital Market. Integrated supervision in management. To ensure the implementation of GCG in line with the SDGs, it is necessary to

\footnotetext{
${ }^{18}$ Kasmir. Dasar dasar Perbankan.Rajagrafrindo Persada. Bandung, 2014, p. 255.

${ }^{19}$ Munir Fuady. Hukum Tentang Merger. Citra Aditya Bakti. Bandung, 2008, p, 30.
} 
conduct a sharia-based Internal Audit and External Audit to be subsequently approved by the National Sharia Supervisory Board.

Second, the plan for implementing the SDGs Program. The banking plan must meet the fulfillment points of SDGs such as Universality, Leaving No one behind, Interconnectedness and Indivisibility, Inclusiveness and Multi-Stakeholder Partnerships. implementation of the Plan for implementing SDGs was not difficult with some of the Standards or Models that have been provided internationally such as SDGS Compass, Framework Five Step, GRI UNGC Business and UCTAD ISAR $^{20}$ : Banking Institutions have specificity to implement the SDGs provisions with the provision of the establishment of a Business Plan as stated in PBI 12/21 / PBI / 2010 and Financial Services Authority Circular Number 8 / SEOJK.03 / 2018 concerning the Business Plan for Sharia Bank and Sharia Business Unit with the obligation of Sharia Banking to provide certain documents such as :

a. Executive Summary which contains the direction of Sharia Banking policies in the short and medium term.

b. Management Strategy to predict and prevent operational risks that prevent the bank from operating and in the context of implementing the direction of banking policy, Bank also could implement mode of management as issued byThe World Wide Fund and the Financial Services Authority 21

c. Projection of the Financial Report to adjust the budget and program in implementing the direction of sharia banking policy, including in this case concerning the projected ratio and funding plan.

There are two ways that Sharia banking can perform its functions namely independently and / or in cooperation with third parties such as Philanthropy Parties, Business Parties, and Other Institutions who capable in law to do so. In several considerations, a Sharia Bank can conduct legal relations with third parties or partnerships or partnerships to assist in the completion of the SDGS project; Government, fellow Islamic and private banks. The existence of such cooperation is based on 4 (Four) pillars that must be fulfilled by the state namely the Social Pillar, the Law Pillar, the Environmental Pillar and the Economic Pillar simultaneously. ${ }^{22}$ Internationally, the call for all countries to work together in implementing the SDGs is reflected through the two international guidelines, "Multi-Stakeholder Partnerships in the Context of the Agenda 2030 A Practice-Based Analysis of Potential Benefits, Challenges and Success Factors" and "Partnering for Sustainable Development Guidelines for Multistakeholder Partnerships to Implement the 2030 Agenda in Asia and the Pacific." 23

In line with the two Guidelines, Indonesia through the National Development Acceleration Agency (Bappenas) and International Organizations such as INFID, the IAS UNU also sought a draft guideline on multistakeholder partnerships. ${ }^{24}$ Some legislation that implies the need for cooperation between Sharia Bank and third parties in Article 19 paragraph (1) in conjunction with Article 21 paragraph (1) and paragraph (2) of the Presidential Regulation Number 15 of 2010 concerning the

\footnotetext{
${ }^{20}$ Ersa Tri W. Dampak SDGs dalam Laporan Keuangan dan Peran Penting Akuntan. Majalah Akuntan Indonesia. EDISI JUNI 2018, p. 24-26, http://etw-accountant.com/dampak-sdgs-dalam-laporan-keuangan-dan-peran-penting-akuntan/

${ }^{21}$ Otoritas Jasa Keuangan and World Wide Fund. Integrasi Lingkungan, Sosial dan Tata Kelola yang baik : Panduan untuk

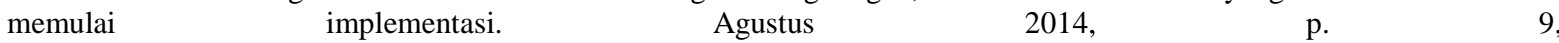
https://d2d2tb15kqhejt.cloudfront.net/downloads/panduan_integrasi_lst_untuk_memulai_1.pdf

${ }^{22}$ Indonesia Climate Change Trust Fund, SDGS, Retrieved from https://www.icctf.or.id/sdgs/, Accessed on June 6, 2019.

${ }^{23}$ United Nations University, Partnering for Sustain-able Development Guidelines for Multistakeholder Partnerships to Implement the 2030 Agenda in Asia and the Pacific, 2018, , Retrieved from https://www.unescap.org/sites/default/files/MSP\%20Guidelines.pdf, Accessed on June 6, 2019

${ }^{24}$ Bappenas, INFID, UNU IAS, Draft II Tentang Panduan Kemiytaan Multipihak untuk Pelaksanaan Tujuan Pembangunan Berkelanjutan (TPB/SDGS) di Indonesua, Jakarta, 2018, p. 16, https://localisesdgsindonesia.org/asset/file/2018/08/bappenas-draft-ii-panduan-kmp.pdf
} 
Acceleration of Poverty Reduction, if the Government Regions request assistance from Sharia Commercial Banks in implementing poverty alleviation projects, then Islamic Bank have obligations through cooperation and partnerships to regulate the Regional Expenditures Budget used.

Several possibilities occur in partnership or partnership activities, namely Sharia Bank as fund providers, Sharia Bank as fund managers or Sharia Bank, not as fund managers and / or fund providers;

a. In the case of Sharia Banks as providers of funds, the financing scheme will be carried out using financing. Sharia Financing is regulated in the Financial Services Authority Regulation Number 31 / POJK.05 / 2014 concerning the Implementation of Sharia Financing Businesses which are divided into financing for Sale, Investment and / or Services. The Mixed Agreement is also implemented in the Financial Services Authority Regulation Number 43 / POJK.04 / 2015 concerning Contracts that are used in Sharia Securities Issuance in the Capital Market which describes the characteristics of Mudharabah Securities, Musyarakah and Wakalah.

b. In the case of a Sharia Bank as a fund manager, the agreement scheme that will be carried out is to use the Mudharabah Agreement. Mudharabah agreement can be used because the Bank can actively choose the provider of funds that is oriented towards the development of the SDGs program so that the profits will be channeled directly to third parties or individual sharia banking projects. Based on Bank Indonesia Decree Number 32/34 / KEP / DIR dated 12 May 1999. Besides financing using the Mudharabah Agreement, the Bank can become a fund manager for SDGs projects through Investment facilities based on the Murabahah Agreement as described in the Fatwa of the National Sharia Council Number 04 / DSN-MUI / I / IV / 2000 to procure goods on behalf of customers.

c. In addition to the Agreement, Sharia Bank can also use social functions in banking services, namely Zakat and Endowments. Zakat is regulated in Law No. 23 of 2011 concerning the Management of Zakat. The Funding Agreement in Zakat is divided into Early Business Financing using Qardhul Hasan, medium financing using Qard and independent financing using Mudharabah. ${ }^{25}$

Third, Corporate Social Responsibility (CSR) as the implementation of SDGS. If the Sharia Bank intends to implement the SDGs program independently, then the Sharia Bank can carry out financing and CSR programs that are guided by the SDGs provisions and related Laws and Regulations. Ali Syukron argues that CSR has been implemented in the life and economy of Islam through the Qur'an with the principle to preserve and harmonize the environment, strive for the elimination of poverty, put forward something clean moral rather than something that is morally dirty, even though it brings greater profits and CSR done honestly and trustworthy. Corporate Social Responsibilities should pay attention to factors such as Proximity or geographical position, Relevance of Activity, Magnitude or promotive effects of the CSR for the giver and the recipient.

In line with these noble goals, CSR must be carefully planned with the existence of a sustainability concept that can be carried out with the principle of partnership by paying attention to the availability of funds, environmental mission, social responsibility, implementation in community policies and benefits to be provided. ${ }^{26} \mathrm{CSR}$ is not only a place of obligation but also takes into account the benefits that CSR players will get, such as increasing sales of market share to the strengthen position, increase marketing capabilities, reduce operating costs and increase investor

\footnotetext{
${ }^{25}$ Dahnila Dahlan, Bank Zakat : Pengelolaan Zakat dengan Konsep Bank Sosial berdasarkan prinsip syariah, Jurnal Ekonomi dan Bisnis Islam, Volume 4, Number 2, Juli - Desember 2018,p. 162, $\underline{\text { https://e- }}$ journal.unair.ac.id/JEBIS/article/download/10720/6190

${ }^{26}$ Daniri, Mas Achmad. Standarisasi Tanggung Jawab Sosial Perusahaan. Kadin Indonesia. Year 2009, http://kadinindonesia.or.id/enm/images/dokumen/KADIN-167-3770-15042009.pdf, p, 2.
} 
attractiveness. Corporate Social Responsibilities should not only be aimed at SDGs programs that are environmentally oriented, but also on social and community issues as reflected in Law No. 40 of 2007 concerning Limited Liability Companies in conjunction with Law Number 32 Year 2009 concerning the Environment in conjunction with Law Number 13 Year 2011 concerning Handling of Poor People juncto Regulation of the Financial Services Authority Number 51 / POJK.03 / 2017 juncto Government Regulation 47 of 2012 concerning Social and Environmental Responsibilities of Limited Liability Companies. Corporate Social Responsibilities can be used in poverty alleviation programs with Islamic Commercial Banks actively setting aside their income for the needs of the poor. In addition to the development of MSMEs, CSR can be carried out by implementing MSME institutional development strategies, funding, services, human resources and efficiency. ${ }^{27}$

\section{CONCLUSION}

Based on the legal research, the conclusions could be concluded are : The urgency for Sharia Business Unit to become Sharia Bank based on legislative orders and government policies to unite the Sharia Banking system into a single entity, but the State of Sharia Businesses are obliged to receive assistance from the Parent Bank (Conventional) related to handling resource skill issues human, organization and capital. That is why the Conventional Bank must prepare spin-off process not only in structural organization but also how the Sharia Business Unit can face SDGs era as its responsibilty of parent bank. The Sharia Business Unit which has become a Sharia Bank is obliged to apply the SDGS principle as an obligation as mandated by the government in several laws and regulations. Sharia Banks can play a role by making management preparation steps, implementing banking services according to the aims and objectives of the SDGs and implementing CSR following the SDGS.

\section{SUGGESTION}

Based on this legal research, the suggestion could be given is government, sharia bank and government shall remain coordinated and synergized to do assesment whether a sharia bank is already ready in administration, asset and market target to ensure the sustainable operation and future obstacles to new spin off bank.

\section{REFERENCES}

\section{Books}

Fuady, Munir, 2008, Hukum Tentang Merger. Citra Aditya Bakti. Bandung. Kasmir, 2014, Dasar dasar Perbankan.Rajagrafrindo Persada. Bandung. P. Usanti, Trisadini dan Abdul Somad, 2018, Hukum Perbankan, Kencana Prenada, Jakarta.

\section{Journals}

Dahlan, Dahnia. 2018. "Bank Zakat : Pengelolaan Zakat dengan Konsep Bank Sosial berdasarkan prinsip syariah", Jurnal Ekonomi dan Bisnis Islam, Volume 4, Nomor 2, Juli - Desember 2018.

Ishartono and Santoso Tri R. 2016. "Sustainable Development Goals (SDGS) dan Pengentasan Kemiskinan", Share : Social Work Jurnal, Volume 6, Nomor 2, Tahun 2016, p.159.

Khotibul Umam. 2010. "Peningkatan Ketaatan Syariah Melalui Pemisahan (spin-off) Unit Usaha Syariah Bank Umum Konvensional”, Mimbar Hukum, Volume 22, Nomor 3, Oktober 2010, P. 609

Lukmanul Hakim. 2019. "Credit Banking in Business Law Perspective”, Jurnal Ilmu Hukum Unifikasi, Volume 6, Nomor 1, Tahun 2019, p. 53.

\footnotetext{
${ }^{27}$ Krisnamurthi, Rancangan Keberpihakan Terhadap Ekonomi Rakyat, retrieved from www.bmm-online.org.
} 
Muhammad Fardan N, "Mengawail Sustainable Development Goals (SDGS) Meluruskan Orientasi Pembangunan yang berkeadilan, Sosioreligius, Volume 1, Nomor 1, June 2015, p.81.

Nasuha, Amalia, "Dampak Kebijakan Spin-Off Terhadap Kinerja Bank Syariah". Al-Iqtishad Volume 4 Nomor 2, 2016.

Sulasi Rongiyati, "Pengembangan Perbankan Syariah Melalui Pelaksanaan Perbankan Syariah Melalui Pelaksanaan Kewajiban Pemisahan Unit Usaha Syariah”, Negara Hukum, Volume 6, Nomor 1, Juni 2015, p. 66.

Thomas Pogge and Mitu Sengupta, "The Sustainable Development Goals as Drafted : Nice Idea, Poor Execution", Washington International Law Journal Association, Volume 24, Nomor 3, 2015, P. 573-579

\section{Paper or Speech}

Abdul Ghafar Ismail. Et.all, "Ecosystem in Islamic Finance and Its Link with SDGs". 3th International Conference on Islamic Economics and Finacial Inclusion, Universitas Muhammadiyah Yogyakarta, July $11 \quad-\quad 12$ http://iciefi.umy.ac.id/wpcontent/uploads/2018/07/Prof.-Abdul-Ghaffar-ecosystem IF.pdf

Bappenas, INFID dan UNU IAS, "Draft II Tentang Panduan Kemiytaan Multipihak untuk Pelaksanaan Tujuan Pembangunan Berkelanjutan (TPB/SDGS) di Indonesia”, Jakarta, 2018, https://localisesdgs-indonesia.org/asset/file/2018/08/bappenas-draft-ii-panduan-kmp.pdf

Daniri, Mas Achmad. "Standarisasi Tanggung Jawab Sosial Perusahaan”. Kadin Indonesia,March 15,2009, http://kadin-indonesia.or.id/enm/images/dokumen/KADIN-167-3770-15042009.pdf,

Islamic Development Bank and United Nations Development Program. "Islamic finance partnerships key to implementing Sustainable Development Goals", September 22, 2016, https://www.isdb.org/news/idb-and-undp-islamic-finance-partnerships-key-to-implementingsustainable-development-goals

Otoritas Jasa Keuangan and World Wide Fund. "Integrasi Lingkungan, Sosial dan Tata Kelola yang baik : Panduan untuk memulai implementasi”. Agustus 2014, https://d2d2tb15kqhejt.cloudfront.net/downloads/panduan_integrasi_lst_untuk_memulai_1.pdf

Rami Ahmad. "The Potential of Islamic Finance in Achieving the SDGs : Sustainable Development Transition Forum 2017", Incheon, Republic of Korea, 2017, https://www.asef.org/images/docs/2_Dr\%20Rami\%20AHMAD_IDB.pdf

Tri W, Ersa. "Dampak SDGs dalam Laporan Keuangan dan Peran Penting Akuntan. Majalah Akuntan Indonesia. June 2018, http://etw-accountant.com/dampak-sdgs-dalam-laporankeuangan-dan-peran-penting-akuntan/

Weber, Olaf, "Financial Sector and The SDGs: Interconnections and Future Directors". Centre for International Governance Innovation Papers,Volume 201,November 2018 https://www.cigionline.org/sites/default/files/documents/Paper\%20No.201web.pdf

\section{Internet}

Bank Jatim. "Profil Bank Jatim", https://bankjatim.co.id/id/tentang-bankjatim/manajemen/strukturorganisasi , Accessed in 14 July 2019.

Indonesia Climate Change Trust Fund, "SDGS", https://www.icctf.or.id/sdgs/, Accessed on 6 Juni 2019.

Krisnamurthi, "Rancangan Keberpihakan Terhadap Ekonomi Rakyat",www.bmm-online.org, Accessed in 14 July 2019 